\title{
Clonal evolution and progression of 20-methylcholanthrene-induced squa- mous cell carcinoma of mouse epidermis as revealed by DNA instability and other malignancy markers
}

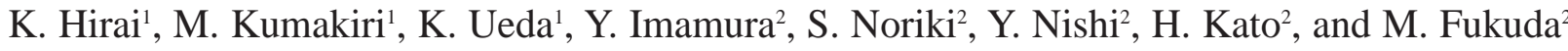 \\ 'Department of Dermatology, Fukui Medical University, Matsuoka, Yoshida-Gun, 910-1193, Fukui, Japan and \\ ${ }^{2}$ Department of Pathology, Fukui Medical University, Matsuoka, Yoshida-Gun, 910-1193, Fukui, Japan
}

Accepted: 2/3/01

Key words: 20-methylcholanthrene (20-MC), SCC, DNA instability, cancer markers

\section{SUMMARY}

We examined the clonal evolution of skin malignant lesions by repeated topical applications of 20 methylcholanthrene (20-MC) to the skin, which induces hyperplastic epidermis, papillomatous lesion and invasive carcinoma in mice. The lesions were examined histologically and immunohistochemically with anti-single-stranded DNA after acid hydrolysis (DNA-instability test), p53, VEGF, DFF45, PCNA and AgNORs parameters analyses. Multiple clones with increased DNA instability comparable to that of invasive carcinoma were noted in early-stage (2-6 weeks) hyperplastic epidermis, and their number increased in middle (7-11 weeks), and late-stages (12-25 weeks) of hyperplastic epidermis, indicating that they belong to the malignancy category. All papillomatous lesions and invasive carcinomas showed a positive DNA-instability test. Positive immunostaining for various biomarkers and AgNORs parameters appeared in clones with a positive DNA-instability test in earlyor middle-stage hyperplastic epidermis, and markedly increased in late-stage hyperplastic epidermis, papillomatous lesions and invasive carcinomas. The percentage of PCNA-positive vascular endothelial cells was significantly higher in VEGFpositive lesions with a positive DNA-instability test and became higher toward the late-stage of progression. Cut-woundings were made to papillomatous and invasive carcinoma lesions, and the regeneration activity of vascular endothelial cells was determined by using flash labeling with tritiated thymidine $\left({ }_{3} \mathrm{H}-\mathrm{TdR}\right)$. In small papillomatous lesions, vascular endothelial cells showed regenerative response, but the response was weak in large lesions. No such response was noted in invasive carcinomas; rather, cut-wounding induced collapse of blood vessels, which in turn induced massive coagulative necrosis of cancer cells. These responses can be interpreted to reflect exhausted vascular growth activity due to excessive stimulation by VEGF-overexpression, which was persistently seen from hyperplastic epidermis to invasive carcinoma.

\section{INTRODUCTION}

Several groups have investigated the immediate and long-term effects of single or repeated topical surface applications to the mouse dorsal skin of various chemical carcinogens (Iversen and Ever- 
sen, 1962; Iversen and Bjerkbes, 1963; Iversen et al., 1976; Fukuda et al., 1978; Iversen et al., 1982; Colapietro et al., 1993; Ishikawa et al., 1999; Reddig et al., 1999; Owen et al., 1999; Saran et al., 1999; Wei et al., 1999; Coghlan et al., 2000). These studies concluded that chemical carcinogens could cause a variety of skin lesions ranging from hyperplastic epidermis to invasive carcinoma.

Recent advances in molecular biology have allowed the detection of changes in various biomarkers in the carcinogen-treated mouse epidermis during the course of carcinogenesis. For example, activated Ha-ras oncogene with carcinogenspecific point mutations has been demonstrated in the mouse skin epidermis treated with various chemical carcinogens at various stages of carcinogenesis (Brown et al., 1990; Bowden et al., 1991; Nelson et al., 1992; Vassar et al., 1992; Kemp et al., 1993, 1994; Finch et al., 1996; Larcher et al., 1996; Tober et al., 1998). Furthermore, cyclin D1 gene rearrangement, amplification and protein overexpression, indicating cyclin deregulation, have been found in mouse skin papillomatous lesions induced by carcinogens (Robles et al., 1995; Stern et al., 1998). Similarly, overexpression of transforming growth factor (TGF) $\alpha$ (Vassar et al., 1992) or $\beta$ (Cui et al., 1994; Stern et al., 1998) was demonstrated to play a central role in chemically-induced papilloma formation and carcinogenesis (Go et al., 1999). Changes in the expression of keratins have been reported during the course of chemically-induced mouse skin carcinogenesis (Gimenz-Conti et al., 1990; Huitfeldt et al., 1991; Caulin et al., 1993; Stern et al., 1998). Moreover, mutations in the p53 gene were identified in the late stages of chemically-induced tumor progression and were closely associated with poorly differentiated phenotype (Ruggeri et al., 1991) and the lack of such phenotype in p53 knockout mice greatly enhanced malignant progression (Kemp et al., 1993) in mouse skin chemical carcinogenesis. Immunohistochemically identified cells positive for mutant p53 protein showed close intercorrelation with the degree of histological dysplasia induced by chemical carcinogens (Lu et al., 1997; Stenback et al., 1998).

Angiogenesis is a crucial process for tumor growth, and vascular endothelial growth factor (VEGF) is a specific mitogen for endothelial cells (Leung et al., 1989), which is overexpressed at the later stages of mouse skin chemical tumor progression (Larcher et al., 1996;
Bolontrade et al., 1998; Tober et al., 1998).

DNA fragmentation factor (DFF) is an important factor in the cascade leading to apoptosis. DFF is activated by caspase- 3 and is involved in the formation of nuclear DNA fragments. DFF is a heterodimeric protein of $40 \mathrm{kDa}$ and $45 \mathrm{kDa}$, which is activated when it is cleaved by caspase-3. Of the two enzymatically cleaved fragments, the $40 \mathrm{kDa}$ fragment (DFF40) is the active component responsible for triggering chromatin condensation (Liu et al., 1997; Enari et al., 1998; Sabol et al., 1998; Sakahira et al., 1998; Sasaki et al., 1999).

Cell proliferation as well as apoptosis-related factors such as p53 and DFF are useful features to allow investigating the dysfunctional proliferative regulation of cancerous transformation. The proliferative activity in chemically-induced lesions has been evaluated by immunohistochemical staining of different cell proliferation-related proteins such as MIB-1 (Soballe et al., 1996), PCNA (Cui et al., 1994; Stenback et al., 1998; Stern et al., 1998; Zhang et al., 1998) and AgNORs (Carbonelli et al., 1994). In all the above studies, significant increases were detected in cellular proliferation during various phases of neoplastic transformation.

The above studies also detected abnormal gene expression and protein synthesis, disturbed cytodifferentiation, and stimulated proliferative activity during the course of progression of malignancy, but the results were not consistent and no specific markers were identified for detecting malignant clones, although the abnormalities were statistically significant.

Fukuda et al. (1986, 1993) found that nuclear DNA of malignant neoplastic cells is always and without exception much more unstable than that of comparable benign tumor cells and normal cells, irrespective of epithelial or mesenchymal origin, thus yielding a larger amount of single-stranded DNA by acid hydrolysis $\left(2 \mathrm{~N} \mathrm{HCl}, 30^{\circ} \mathrm{C}\right.$ for 20 $\min )$. They developed a method for differential fluorescent or immunohistochemical staining of malignant neoplastic cells after denaturation of nuclear DNA by acid hydrolysis. They further used the technique to identify malignant clones in socalled border-line neoplastic lesions (Nitta et al., 1993; Otaki et al., 1994; Tsuzuki et al., 1994; Azuchi et al., 1998; Khaled et al., 2000).

In the present study, we used the above method to detect malignant clones by increased DNA instability (DNA-instability test) during the course of mouse skin hyperplastic epidermis, papillomatous 
lesion and invasive carcinoma induced by repeated topical applications of 20-methylcholanthrene (20$\mathrm{MC})$. In order to identify the biological characteristics of these malignant clones of positive DNAinstability test, immunostaining for other biomarkers such as p53, VEGF, DFF45, PCNA, and AgNORs was also examined. Double immunostaining for CD34 and PCNA was also applied to the lesions to demonstrate the direct intercorrelation between VEGF production and proliferative activity of vascular endothelial cells in the neighboring stromal tissue. In order to examine the reactive changes of vascular endothelial cell proliferation in response to wound stimulation, cut woundings were made in papillomatous lesions and invasive carcinomas and were labelled with tritiated thymidine $\left({ }_{3} \mathrm{H}-\mathrm{TdR}\right)$ for autoradiography.

\section{MATERIALS AND METHODS}

\section{Animals and carcinogen treatment}

Male mice (dd-strain, 5 weeks old, Japan SLC Co., Tokyo, Japan) were used in all experiments. They were housed in plastic cages in a barrier-sustained animal room with a $12 / 12 \mathrm{~h}$ light/dark cycle at $22 \pm 2^{\circ} \mathrm{C}$ and $55 \pm 5 \%$ relative humidity, and provided with commercial pellet diet (Clea Japan Inc., Tokyo) and water ad libitum. After 1-week acclimation, the dorsal region of each mouse was clipped clean of hair with an electric hair clipper. 20 -MC solution $(0.5 \%$, Sigma-Aldrich, St. Louis, MO, USA) dissolved in acetone was applied topically twice a week on the dorsal epidermis. A total of 100 mice were used for the present study. Mice were sacrificed by cervical dislocation under ether anesthesia. The experimental protocol was approved by the Ethics Review Committee for Animal Experimentation of Fukui Medical University.

Immunohistochemical staining of paraffinembedded sections with polyclonal anti-singlestranded DNA antibody after acid hydrolysis to demonstrate DNA instability (DNA-instability test)

A total of 70 mice with hyperplastic epidermis, papillomatous lesions and invasive carcinoma (225 weeks) were used for these studies. All materials were fixed with buffered $10 \%$ formalin for 24 $\mathrm{h}$ at room temperature, and $4 \mu \mathrm{m}$ paraffin embedded sections were prepared. They were deparaffinized and rehydrated by ethanol. (a) Preblocking

After washing in water, intrinsic peroxidase was blocked with $0.03 \% \quad \mathrm{H}_{2} \mathrm{O}_{2}$ solution dissolved in absolute methanol at $20^{\circ} \mathrm{C}$ for 15 minutes and rinsed with $\mathrm{PBS}(\mathrm{pH}$ 7.4). The sections were mounted with $2 \%$ skim-milk (Yukijirushi, Sapporo, Japan) dissolved in PBS ( $\mathrm{pH} 7.4$ ) at $37^{\circ} \mathrm{C}$ for 20 min to block the background adsorption of antiserum. Then they were reacted with the blocking solution (Histofine, SAB-PO, Nichirei, Tokyo) at $20^{\circ} \mathrm{C}$ for $5 \mathrm{~min}$.

(b) HCl hydrolysis and immunohistochemical staining of single-stranded DNA by the ABC method

Sections were then washed in water, followed by acid hydrolysis with $2 \mathrm{~N} \mathrm{HCl}$ at $30^{\circ} \mathrm{C}$ for $20 \mathrm{~min}$, and then washed in water again. They were reacted overnight with polyclonal antibody to cytidine (Biogenesis, ONF, UK, 1:1,500 dilution with PBS, $\mathrm{pH} 7.4$ ) at $4^{\circ} \mathrm{C}$ then rinsed with PBS (pH 7.4). Sections were reacted with biotinylated goat anti-rabbit $\mathrm{IgG}$ (Histofine) at $37^{\circ} \mathrm{C}$ for $40 \mathrm{~min}$, rinsed with PBS ( $\mathrm{pH} 7.4$ ) and allowed to react with the avidinbiotin peroxidase complex (Histofine) at $37^{\circ} \mathrm{C}$ for 30 min, then rinsed with PBS (pH 7.4).

\section{(c) Co-DAB reaction}

In order to visualize the peroxidase color reaction, sections were incubated with DAB (3,3'-diaminobenzidine tetrahydrochloride) cobalt solution (DAB, Dogin, Kumamoto, Japan, $50 \mathrm{mg}$ dissolved in 100 $\mathrm{ml}$ of $0.05 \mathrm{M}$ Tris-HCl buffer, $\mathrm{pH} 7.4$, added with 2 $\mathrm{ml}$ of $1 \% \mathrm{CoCl}_{2}$ and $10 \mu \mathrm{l}$ of $30 \% \mathrm{H}_{2} \mathrm{O}_{2}$ solution) at $20^{\circ} \mathrm{C}$ for $10 \mathrm{~min}$ and washed in water. Nuclear counterstaining was carried out with Kernechtrot (Kernechtrot, Chroma, Stuttgart, Germany, $100 \mathrm{mg}$ and 5 $\mathrm{g}$ aluminum sulfate dissolved in $100 \mathrm{ml}$ distilled water).

\section{Immunohistochemical staining of p53, VEGF, DFF45 and PCNA}

Serial $4 \mu \mathrm{m}$ thick sections were prepared from the same specimens used for the DNA-instability test as described above. After washing in water, intrinsic peroxidase was blocked with $0.03 \% \mathrm{H}_{2} \mathrm{O}_{2}$ solution dissolved in absolute methanol at $20^{\circ} \mathrm{C}$ for $15 \mathrm{~min}$ and rinsed with PBS ( $\mathrm{pH}$ 7.4). Sections were irradiated in a poly-propylene slide holder with a cap filled with $10 \mathrm{mM}$ Na-citrate buffer ( $\mathrm{pH}$ 6.0), over a period of $10 \mathrm{~min}$, using an autoclave (Hirayama, $1.5 \mathrm{~kW}$, Tokyo, Japan), then mounted with $2 \%$ skimmilk (Yukijirushi) dissolved in PBS ( $\mathrm{pH} \mathrm{7.4),} \mathrm{at}$ 
$37^{\circ} \mathrm{C}$ for 30 min to block the background adsorption of antiserum. They were further reacted with the blocking solution (Histofine) at $20^{\circ} \mathrm{C}$ for $5 \mathrm{~min}$. This was followed by reactions with the following primary antibodies, respectively, at $4{ }^{\circ} \mathrm{C}$ overnight; monoclonal anti-p53 antibody (Ab-3, Calbiochem, MA, USA, 1:100 dilution with PBS, pH7.4), polyclonal anti-VEGF antibody (Neomarkers, CA, USA, 1:100 dilution with PBS pH 7.4), polyclonal anti-DFF45 antibody (Novocastra, Newcastle, UK, 1:200 dilution with PBS, pH 7.4), monoclonal anti-PCNA antibody (PC-10, Calbiochem, 1:100 dilution with PBS, $\mathrm{pH}$ 7.4). Then the sections were rinsed with PBS ( $\mathrm{pH}$ 7.4) and further reacted with biotinylated anti-mouse IgG (Histofine) for monoclonal anti-p53 and antiPCNA antibodies, and with biotinylated anti-rabbit IgG (Histofine) for polyclonal anti-VEGF and antiDFF45 antibodies, respectively, followed by rinsing with PBS (pH 7.4). They were allowed to react with the avidin-biotin-peroxidase complex (Histofine) at $37^{\circ} \mathrm{C}$ for $30 \mathrm{~min}$ and rinsed with $\mathrm{PBS}(\mathrm{pH} 7.4)$. In order to visualize the peroxidase color reaction, sections were incubated with DAB solution $(10 \mathrm{mg}$ dissolved in $50 \mathrm{ml} \mathrm{PBS,} \mathrm{pH} 7.4$ ) at $20^{\circ} \mathrm{C}$ for $10 \mathrm{~min}$ and washed in water. Nuclear counterstaining was performed with hematoxylin.

Evaluations of immunohistochemical staining for DNA-instability test, p53, VEGF, DFF45 and PCNA

As for the DNA-instability test, foci with more than several positively stained epithelial cells were regarded as positive. The PCNA-index of hyperplastic epidermis, papillomatous lesions and invasive carcinoma represented the percentage of positively stained cells among more than 500 epithelial cells in each lesion, and was determined in both DNA-instability test-positive and -negative areas, respectively. In the same areas in serial sections, foci with $>5 \%$ cells positively stained for p53, VEGF and DFF45 were regarded positive after counting more than 500 epithelial cells.

\section{AgNORs}

Specimens taken from the same tissues used in the above experiments were used for AgNORs assay. Deparaffinized and ethanol rehydrated specimens were washed in de-ionized and distilled water, and coated with $2 \mathrm{~g} / \mathrm{dl}$ gelatin dissolved in $1 \mathrm{mg} / \mathrm{dl}$ formic acid solution added with twice the volume of $50 \mathrm{~g} / \mathrm{dl}$ silver nitrate, and allowed to react at $20^{\circ} \mathrm{C}$ for 15 min under a safety light (No. LA. Kodak, NY).
The specimens were then fixed with Fuji-fix solution (Fujifix, Fuji Photo Film, Tokyo, $445 \mathrm{~g}$ dissolved in 2,000 $\mathrm{ml}$ of de-ionized and distilled water) for $1 \mathrm{~min}$ at room temperature and thoroughly washed in de-ionized and distilled water. No nuclear counterstaining was performed.

\section{Quantitative analysis of the number, mean and largest sizes and maximum shape irregularity of AgNORs}

The color image analysis software MacScope ver 2.56 (Mitani Corp., Fukui, Japan) was used. The image of an optical field of a specimen stained by the AgNORs technique (viewed by x1000 objective) was projected on the cathode ray tube (CRT). The total number of AgNORs in one optical field or in each nucleus was counted manually. The total area $\left(\mu \mathrm{m}^{2}\right)$ of all AgNORs-positive nuclei in one optical field or in each nucleus was automatically determined by the image analyzer software. The mean \pm SD of AgNORs area in each optical field or in each nucleus was computed. Three to five optical fields, i.e., about 100 cells were examined in each specimen. The mean value of the maximum shape irregularity of AgNORs expressed as the degree of deviation from a regular circle, was computed for the most irregularly shaped AgNOR in 10 nuclei in each specimen, by the same application, using a printed photograph of the image viewed on the CRT with a final magnification of $\mathrm{x} 1,000$.

\section{Immunohistochemical double staining for CD34 and PCNA}

Serial $4 \mu \mathrm{m}$ thick sections prepared from the same specimens used for other staining procedures were used in these assays. After washing in water, the intrinsic peroxidase was blocked with $0.03 \% \mathrm{H}_{2} \mathrm{O}_{2}$ solution dissolved in absolute methanol at $20^{\circ} \mathrm{C}$ for $15 \mathrm{~min}$ and rinsed with PBS (pH 7.4). Sections were irradiated in a poly-propylene slide holder with a cap filled with $10 \mathrm{mM}$ Na-citrate buffer $(\mathrm{pH}$ 6.0 ), over a period of $10 \mathrm{~min}$, using an autoclave (Hirayama, $1.5 \mathrm{~kW}$, Tokyo), then mounted with $2 \%$

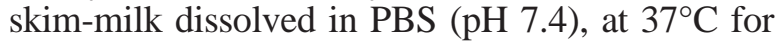
30 min to block the background adsorption of antiserum. They were further reacted with the Histofine blocking solution at $20^{\circ} \mathrm{C}$ for $5 \mathrm{~min}$, followed by reaction with monoclonal rat anti-mouse CD34 antibody (CBR-E8, Southern Biotechnology Associates, Birmingham, AL, USA, 1:200 dilution with $\mathrm{PBS}, \mathrm{pH} 7.4)$ at $4^{\circ} \mathrm{C}$ overnight. They were then rinsed with $\mathrm{PBS}(\mathrm{pH}$ 7.4) and further reacted with 
biotinylated goat anti-rat IgM (A104BS, American Qualex International, CA, USA, 1:50 dilution with $\mathrm{PBS}, \mathrm{pH} 7.4$ ) at $37^{\circ} \mathrm{C}$ for $40 \mathrm{~min}$, followed by rinsing with PBS ( $\mathrm{pH} 7.4)$. Sections were allowed to react with Histofine avidin-biotin-peroxidase complex at $37^{\circ} \mathrm{C}$ for $30 \mathrm{~min}$ and rinsed with $\mathrm{PBS}(\mathrm{pH}$ 7.4). In order to visualize the peroxidase color reaction, sections were incubated with $\mathrm{DAB}$ solution $\left(10 \mathrm{mg}\right.$ dissolved in $50 \mathrm{ml} \mathrm{PBS}, \mathrm{pH} 7.4$ ) at $20^{\circ} \mathrm{C}$ for $10 \mathrm{~min}$ and washed in water. Then sections were reacted with monoclonal anti-PCNA antibody $(\mathrm{pH}$ 7.4) at $4^{\circ} \mathrm{C}$ overnight, rinsed with $\mathrm{PBS}, \mathrm{pH} 7.4$, and further reacted with biotinylated anti- mouse IgG at $37^{\circ} \mathrm{C}$ for $40 \mathrm{~min}$, followed by rinsing with $\mathrm{PBS}(\mathrm{pH}$ 7.4). They were allowed to react with the avidinbiotin peroxidase complex at $37^{\circ} \mathrm{C}$ for $30 \mathrm{~min}$, then rinsed with PBS. For the peroxidase color reaction, sections were incubated with $\mathrm{DAB}$ cobalt solution at $20^{\circ} \mathrm{C}$ for $10 \mathrm{~min}$ and washed in water. Nuclear counterstaining was carried out with Kernechtrot.

\section{Quantitative analysis of immunohistochemical double staining for CD34 and PCNA}

The percentage of PCNA-positive capillary endothelial cells (PCNA-index) in the vicinity of epithelial cell clones positive for VEGF was determined by counting at least 100 endothelial cells. The percentages of VEGF negative zones were also determined as the control.

\section{Wounding experiments}

\section{(a) Procedure}

A total of 30 mice were used in these experiments. A linear wound was made under ether anesthesia using a razor blade. Papillomatous lesions and invasive carcinomas were incised to the muscle layer.

\section{(b) Flash or instantaneous DNA-labeling with ${ }_{3} \mathrm{H}$ -} $T d R$

Flash DNA-labeling was performed by sacrificing animals $30 \mathrm{~min}$ after a single intraperitoneal injection of tritiated thymidine ${ }_{3} \mathrm{H}-\mathrm{TdR}$, approximately $2.0 \mathrm{mCi} / \mathrm{g}$, specific activity, $23 \mathrm{Ci} / \mathrm{mM}$, Radioisotope Center, Tokyo) by using 5 animals each before and $24 \mathrm{~h}$ after cut-wounding of small $(0.5 \mathrm{~cm}$ in diameter $)$, middle $(1.0 \mathrm{~cm}$ in diameter $)$ and large $(1.5 \mathrm{~cm}$ in diameter $)$ papillomatous lesions, and before and 10 and 20 days after cut wounding for invasive carcinoma lesions. All DNA-labeled materials were fixed in $10 \%$ buffered formalin for $24 \mathrm{~h}$ at room temperature and
$4 \mu \mathrm{m}$ paraffin-embedded sections were prepared and deparaffinized and ethanol replaced as described above.

\section{(c) Autoradiography}

All sections were dipped in melted nuclear emulsion (NR-M2, Sakura, Kyoto, Japan) and autoradiographs were developed in FD 111 at $24^{\circ} \mathrm{C}$ for 8 min after exposure in a refrigerator for 4 weeks. The autoradiographs were stained with hematoxylin and eosin.

\section{(d) Quantitative analysis of autoradiography}

The percent labeling index of capillary endothelial cells was determined for small, middle and large papillomatous lesions in three different areas, top, middle and basal zone of a capillary. More than 200 endothelial cells were counted to determine the labeling index of each capillary zone in both papillomatous lesions and invasive carcinoma lesions.

\section{Statistical Analysis}

PCNA-indices (epidermal cell and vascular endothelial cell) and AgNORs parameters are presented as mean $\pm \mathrm{SD}$. Data were analyzed using Students t-test with a $p$ value less than 0.05 considered significant. Comparison of positive lesions for p53, VEGF, DFF45 and DNA-instability test was performed by the chi-square test, the selected level of significance was $p<0.05$. Comparison of different biological parameters (PCNAindices and AgNORs parameters) in DNA-instability test-positive and negative cases were analyzed using Students t-test with a $p$ value less than 0.05 considered significant.

\section{RESULTS}

The histological features of hyperplastic epidermis (2-25 weeks after exposure to 20-MC), papillomatous lesion (7-25 weeks), and invasive carcinoma (12-25 weeks) were determined by routine HE staining. Hyperplastic epidermis were subdivided into three stages, early- (2-6 weeks, before the onset of papillomatous lesions), middle- (7-11 weeks, the hyperplastic epidermis remaining between papillomatous lesions) and late- (12-25 weeks, marginal hyperplastic epidermis continuous with the papillomatous lesions or invasive carcinoma lesions) stages. The normal epidermis of mouse dorsal skin 
is composed of 2-3 layers of squamous cells but the hyperplastic epidermis induced by carcinogen treatment at the early- (3-5 layers), middle- (5-10 layers) and late- (more than 10 layers) stages showed thickening with increased cell layers. However, the degree of cellular atypia in hyperplastic epidermis was mild, and no morphological sign of malignancy was noted. Papillomatous lesion cells had slightly enlarged nuclei with enlarged nucleoli but the polarities were still preserved without invasion and were regarded as benign morphologically. In invasive carcinomas, the loss of polarity with invasion and increased degree of cellular atypia were obvious. Clones with histological characteristics similar to invasive carcinoma but without invasion were also present in the papillomatous lesions.

\section{Immunohistochemical staining}

The percentages of cells positive for p53, VEGF, DFF45, PCNA and AgNORs parameters in relation to the DNA-instability test are summarized for the three types of lesions in Table I.

\section{(a) DNA-instability test}

After hydrolysis with $2 \mathrm{~N} \mathrm{HCl}$ at $30^{\circ} \mathrm{C}$ for $20 \mathrm{~min}$, all cancer cells in all cancer lesions showing invasion (20 lesions) were positively stained without exception with anti-single-stranded DNA antibody indicating increased DNA instability (Fig. 1c). While normal epidermal cells, normal vascular endothelial cells and fibroblasts present in the same slides were all negative.

In 15 sections (1.5 cm long) of early-stage hyperplastic epidermis, only $2(13.3 \%)$ small foci of positively stained cells were detected, but the number increased in the middle ( 7 foci/ 15 sections, $46.7 \%$ ) and late (31 foci/40 sections, $77.5 \%$ ) stages (Fig. 1a). In hyperplastic epidermis, DNA instability positive cells were distributed in a few basal-side layers in the early-stage and almost throughout the entire thickness of the epidermis in the middle to late-stages. Even in the late-stages of hyperplastic epidermis, however, foci with a negative DNAinstability test were still seen between the positively stained foci. However, all cells in all papillomatous lesions (30 lesions) were diffusely positive by the DNA-instability test (Fig. 1b).

\section{(b) p53 immunohistochemistry}

Normal epidermis was negative for p53 staining. Epidermal cells positive for p53 were noted in hyperplastic epidermis and their distribution coin- cided well with the foci of positive DNA instability, at the middle ( 1 foci/7 foci of positive DNA instability, $14.3 \%$ ) and late-stages ( 6 foci/31 foci of positive DNA instability, $19.4 \%$ ), but the number of positive foci was rather small (Fig. 1d). No positive foci were found in 2 foci of positive DNA instability in the early-stage of hyperplastic epidermis. In hyperplastic epidermis, cells positively stained for p53 were distributed in 3-4 layers of the basal side of the epidermis.

In papillomatous lesions, the number of positively stained cells increased and the cells in the lower 5-6 layers were all diffusely positive for p53 (Fig. 1e). Among a total of 30 papillomatous lesions that were all positively stained in the DNA instability test, $14(46.7 \%)$ lesions showed positive staining for p53 and p53-positive cells were often distributed throughout the entire thickness of the lesions. In 20 invasive carcinoma lesions with positive DNA instability, $13(65 \%)$ showed positive p53 staining, which was noticed to be diffusely distributed throughout the entire lesion (Fig. 1f). The percentages of middle and late-stage hyperplastic epidermis with positive DNA instability, papillomatous lesions and invasive carcinoma lesions that were positive for p53 were significantly higher than normal and hyperplastic epidermis with negative DNA-instability $(\mathrm{p}<0.05$, each, Table I).

\section{(c) VEGF immunohistochemistry}

Immunohistochemical staining for VEGF showed homogeneous cytoplasmic staining. The distribution of VEGF-positive cells coincided with the foci of positive DNA instability. The percentages of VEGF-positive cells among foci with positive DNA instability were $0,28.6,41.9 \%$ in early, middle and late-stage hyperplastic epidermis lesions (Fig. 1g), respectively, while those of papillomatous lesions and invasive carcinoma were 60 and $80 \%$, respectively. The differences between groups were significant $(\mathrm{p}<0.05)$ (Fig. 1h, i, Table I). Normal epidermis and hyperplastic epidermis with a negative DNA-instability test were all negative for VEGF.

\section{(d) DFF45 immunohistochemistry}

Immunohistochemical staining for DFF45 showed granular cytoplasmic and perinuclear staining patterns. Normal epidermis and hyperplastic epidermis with a negative DNA-instability test were all negative. The distribution of DFF45-positive cells coin- 






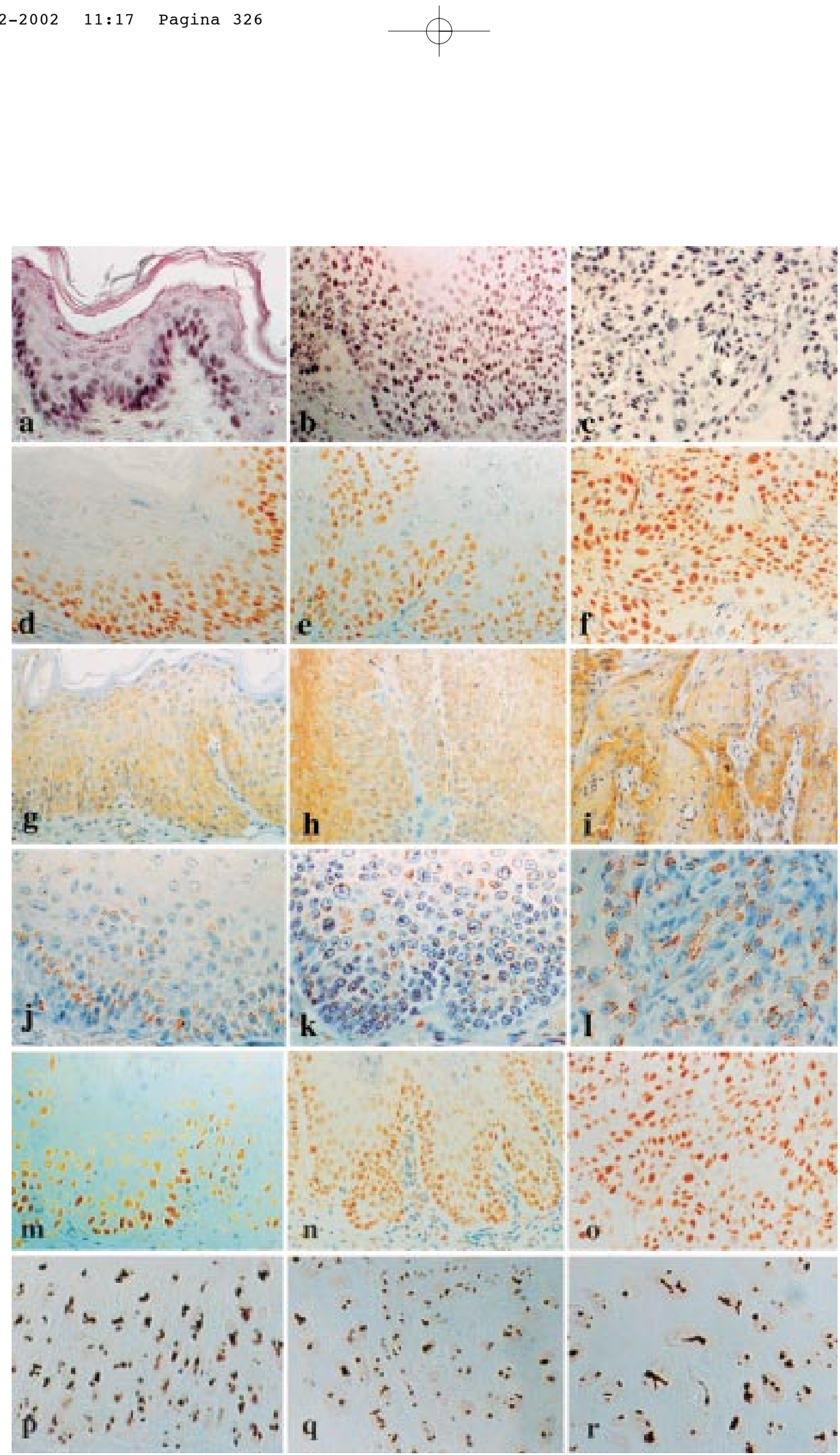

Fig. 1 - Immunohistochemical staining and AgNORs staining. Hyperplastic epidermis (a-p), papillomatous lesion (b-q), and invasive carcinoma (c-r). DNA-instability test (a, b, c) (x100), p53 (d, e, f) (x100), VEGF (g, h, i) (x100), DFF45 (j, k, l) (x100), PCNA (m, n, o) (x100), AgNORs (p, q, r) (x200). 
cided with that of DNA-instability test-positive cells. The percentages of DFF45-positive cells among DNA-instability test-positive foci in early, middle and late-stage hyperplastic epidermis were $0(0 / 2)$, $14.3(1 / 7)$, and $38.7(12 / 31) \%$, respectively, and DFF45-positive cells were distributed in 3-4 layers of the basal side (Fig. 1j). In papillomatous lesions and invasive carcinoma lesions, the percentages of DFF45-positive lesions were 63.3 (19/30) and 85 $(17 / 20) \%$, respectively, and the distribution of the DFF45-positive cells showed diffuse spread throughout the entire lesion (Fig. 1k, 1). Differences in the values between various tissue types were significant (Table I).

\section{(e) PCNA immunohistochemistry}

The distribution of cycling cells positively stained for PCNA in normal epidermis was well defined in the basal layer and sporadic with preserved polarity of cell proliferation and cytodifferentiation (PCNAindex, 7.0\%). In hyperplastic epidermis with a negative DNA-instability test, the distribution of PCNApositive cells was slightly wider, occupying the basal and suprabasal layers (PCNA-index, 15.6\%). In hyperplastic epidermis with foci of positive DNA instability, the distribution of PCNA-positive cells coincided with that of DNA instability positive-cells indicating disturbed polarity of cytodifferentiation (Fig. 1m). The percentage of PCNA-positive cells in the DNA-instability test-positive foci in hyperplastic epidermis at the early, middle and late-stages were 18.2, 21.9 and 41.3\%, respectively (Table I). The values for papillomatous lesions and invasive carcinoma lesions were 46.3 and $72.3 \%$, respectively (Table I), and these PCNA-positive cells were spread throughout the entire lesions with loss of polarity of cytodifferentiation (Fig. 1n, o). Differences in PCNA indices between different tissue types were significant (Table I).

\section{(f) AgNORs parameters}

All AgNORs parameters were significantly higher in hyperplastic epidermis, papillomatous lesions and invasive carcinoma than in normal epidermis (Fig. 1p-r, Table I). The values of invasive carcinoma were also significantly higher than those of hyperplastic epidermis and papillomatous lesions. The values for papillomatous lesions were significantly higher than those for normal epidermis and hyperplastic epidermis at all stages showing negative DNA instability. Moreover, the values of various AgNORs parameters for the DNA-instability test-positive foci of hyperplastic epidermis were significantly higher than those for the DNA-instability test-negative foci, and the values for latestage hyperplastic epidermis were also significantly higher than those for the early and middlestage hyperplastic epidermis (Table I).

\section{(g) Immunohistochemical double staining for $C D$} 34 and PCNA

The percentages of PCNA-positive vascular endothelial cells in the neighboring foci with positive DNA instability in early, middle and late-stage hyperplastic epidermis were 7.7, 9.0 and $11.3 \%$, respectively. Differences in these percentages between these lesions were statistically significant. Moreover, PCNA indices of vascular endothelial cells for hyperplastic epidermis at different stages at foci with a positive DNA instability were all significantly higher than foci with a negative DNA-instability test. PCNA indices of vascular endothelial cells for papillomatous lesions and invasive carcinoma were 13.6 and $16.6 \%$, respectively, and the difference between these two values, and differences between these values and those of different stages of hyperplastic epidermis described above were significant (Fig. 2a, b, Table I).

\section{Wounding experiments}

The labeling index of stromal vascular endothelial cells in small (diameter $0.5 \mathrm{~cm}$ ), middle (diameter $1.0 \mathrm{~cm}$ ), and large (diameter $1.5 \mathrm{~cm}$ ) papillomatous lesions were determined on the autoradiographs prepared by flash labeling with ${ }_{3} \mathrm{H}-\mathrm{TdR}$, before and $24 \mathrm{~h}$ after cut-wounding, and the results are summarized in Fig. 3. The degree of reactive enhancement of endothelial cell proliferative activity was higher in small papillomatous lesions than in large papillomatous lesions, and weak reactivity was noted in the latter only at the top zone of capillaries. In invasive carcinoma lesions, the labeling index of vascular endothelial cells was $10 \%$, and the value decreased markedly to $3 \%$ and $0.5 \%$ at 10 and 20 days after cutwounding, respectively. At 10 days after wounding, many cancer cells showed coagulative necrosis, although they still remained in the perivascular areas in several layers (Fig. 2c). However, at 20 days after wounding, only a small number of cancer cells remained in the perivascular areas and were limited to one or two layers (Fig. 2d). 


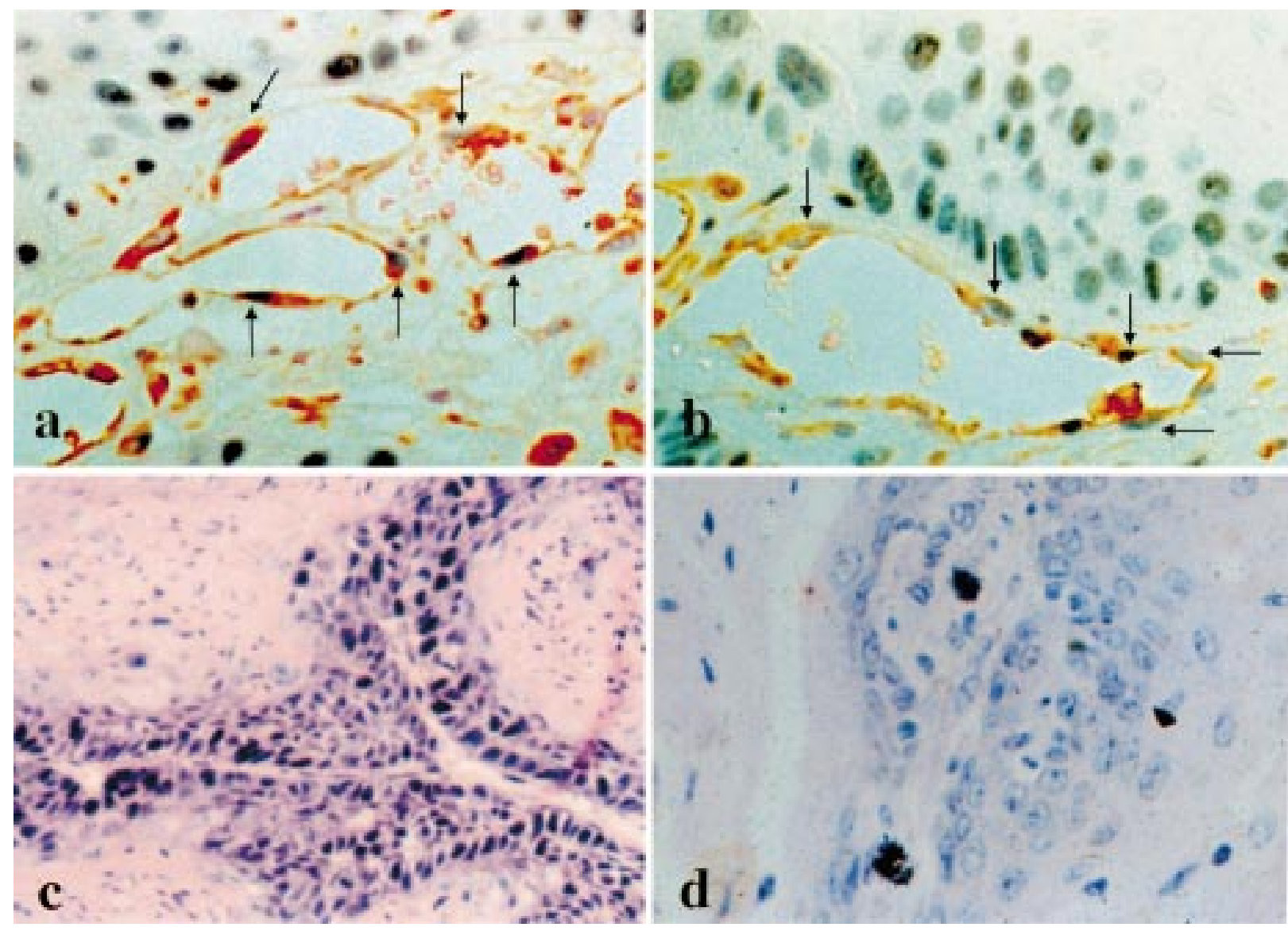

Fig. 2 - Immunohistochemical double staining for CD34 and PCNA. The arrow $(\rightarrow)$ indicates PCNA-positive endothelial cells (a, b), a; papillomatous lesion (x132), b; invasive carcinoma (x160), and autoradiographs of flash labelling with ${ }_{3} \mathrm{H}-\mathrm{TdR}$ at 10 days (c) and 20 days (d) after cut-woundings to invasive carcinomas (c: x100; d: x132).

\section{DISCUSSION}

As described in the introduction, Fukuda et al $(1986,1993)$ reported that the DNA-instability test is a specific marker of malignancy irrespective of epithelial or mesenchymal origin. Based on this finding, they developed the method of differential staining of malignant cells with acridine orange or antisingle-stranded DNA antiserum based on the production of denatured single-stranded DNA in cancer cells as compared to normal cells after acid hydrolysis. Based on the degree of DNA instability by acid hydrolysis, as revealed in the present study, $13.3 \%$ of early, $46.7 \%$ of middle and $77.5 \%$ of late-stage hyperplastic epidermis, and $100 \%$ of papillomatous lesions could be categorized as malignant similar to invasive carcinoma lesions (Fig. 1a-c). Moreover, the percentages of immunostained early and middle- stage hyperplastic epidermis positive for $\mathrm{p} 53$, VEGF, DFF45, PCNA and AgNORs parameters were high in foci of positive DNA instability, and were markedly higher in late-stage of hyperplastic epidermis, papillomatous and invasive carcinoma lesions (Table I).

Wild-type p53 protein plays a significant role in negative regulation of cell proliferation by controlling the entry of mutant cells into the $S$ phase and protecting cells against carcinogenesis (Finlay et al., 1988; Hollstein et al., 1991). The mutated p53 protein can be detected by immunohistochemical methods (Bartek et al., 1990; McGregor et al., 1992; Ro et al., 1993; Ren et al., 1996).

PCNA, an auxiliary protein for DNA polymerase delta, plays an important role in the initiation of cell proliferation (Bravo et al., 1987; Wong et al., 1987; Jaskulski et al., 1988; Tsuji et al., 1993; Yang et al., 


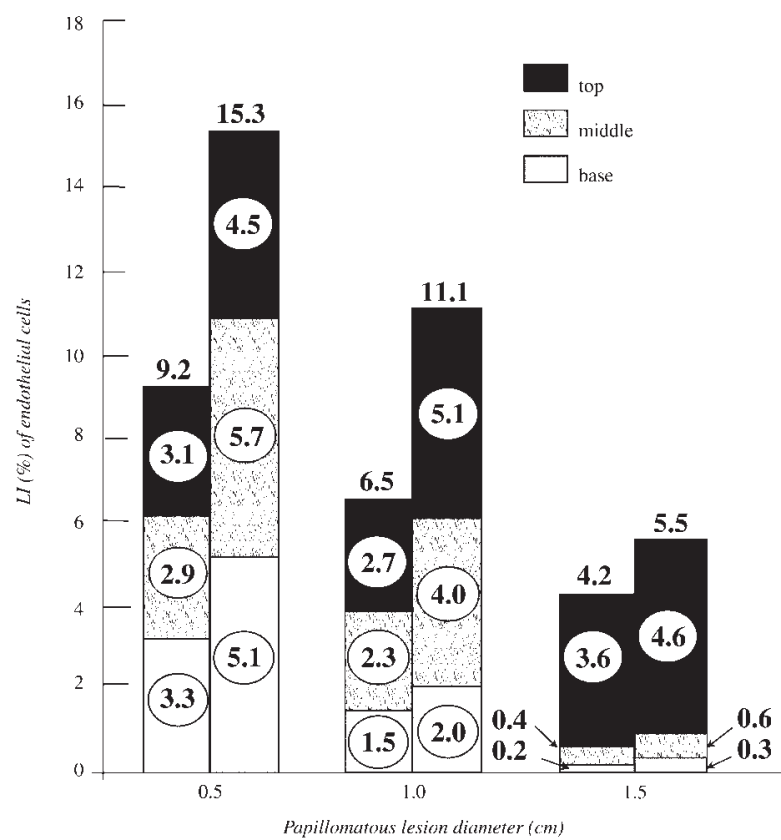

Fig. 3 - Changes of the percent labelling indexes (LI) before (left columns) and $24 \mathrm{~h}$ after (right columns) cut-woundings given to small (diameter $0.5 \mathrm{~cm})$, middle (diameter $1.0 \mathrm{~cm}$ ), and large (diameter $1.5 \mathrm{~cm}$ ) sized papillomatous lesions counted on the autoradiographs made by flash labelling with ${ }_{3} \mathrm{H}-\mathrm{TdR}$

1993). Prescreening with the monoclonal antiPCNA antiserum used in the present study revealed that it reacts with all proliferating cells but not with mature cells and G0 cells. We defined the percentage of PCNA positive cells as the PCNA-index, and this seems to reflect the relative size of the proliferating cell fraction or growth fraction.

Nucleolar organizer regions (NORs) are chromosomal regions where genes for the major ribosomal RNA (18s, 5-8s and 28s) are located (Jordan, 1984). Several studies have shown that the size and number of AgNORs reflect the capacity of cell proliferation (Reeves et al., 1984; Dervan et al., 1989; Trere et al., 1991; Carmen et al., 1992) or the degree of malignancy of neoplasms (Arden et al., 1985; Crocker. 1987; Ayres et al., 1988; Muscare et al., 1991; Kanitakis et al., 1992). Foci of positive DNA instability also showed higher proliferative activity compared to that of normal epidermis and areas of negative DNA instability as revealed by PCNA-immunohistochemistry.

Another important finding obtained by PCNA immunohistochemistry used in the present study is the loss of polarity of PCNA-positive cells especially in the areas of positive DNA instability. In normal epidermis, the PCNA-positive cells were well localized in the basal layer, but the normal distribution was more or less disturbed already in the early or middle-stage of hyperplastic epidermis, especially in the areas of positive DNA instability, and was markedly disturbed in the late stage of hyperplastic epidermis, papillomatous lesions and invasive carcinomas. This apparently indicates the presence of disturbed cell differentiation and proliferation in these lesions, reflecting again the malignant characteristics. Although foci of positive DNA-instability test were also often positive for these biomarkers, it was almost impossible to identify them as malignant based upon simple morphological criteria, because cellular atypia in these foci was often not highly pronounced, although the nuclei and nucleoli were slightly enlarged in late-stage hyperplastic epidermis and papillomatous lesions. We propose here the concept of "procancer" (not pre-cancer) as a stage in the course of carcinogenesis and cancer progression. "Procancer" lesions represent the cancer clone at the very early stage of malignancy without distinguishable morphological atypia but with a positive DNAinstability test and other biomarkers such as p53, VEGF, DFF45, PCNA and AgNORs parameters. We also define the abnormal positivities of these biomarkers including the DNA-instability test as "functional atypia", compared with the commonly defined "morphological atypia". According to these new concepts, we interpret carcinogenesis and progression in the present experiments as follows.

"Procancer" clones with a positive DNA-instability test appeared within 2 weeks after commencing topical applications of 20-MC. The number of these cells increased continuously to the middle and latestage hyperplastic epidermis, associated with positive staining for a variety of biomarkers. In the latestage hyperplastic epidermis, the number of "procancer" foci increased to about 50-, while that of papillomatous lesions was less than 10 per mouse. Furthermore, all cancer lesions that could be identified by morphological atypia appeared only in the preceding papillomatous lesions, and they were not found in hyperplastic epidermis.

In the present study, all papillomatous lesions were positive for the DNA-instability test, indicating that all cells of these lesions were already cancerous. Therefore, the term "papilloma" does not seem to be appropriate and should be replaced with "papillomatous lesion".

The "procancer" clones with high DNA instability would produce multiple sub-clones by enhanced proliferative activity as revealed by 
increased PCNA-positivity. Mutations of p53 gene would also enhance proliferation and reduce the likelihood of apoptotic cell death of "procancer" clones. Furthermore, paracrine secretion of VEGF by "procancer" clones in hyperplastic epidermis would induce dermal neovascularization, which in turn would enhance the growth and transformation of hyperplastic epidermis to papillomatous lesion by providing sufficient levels of oxygen and nutrients. A high percentage of DFF45-positive cells especially in the late-stage hyperplastic epidermis, papillomatous lesions and invasive carcinoma lesions could be interpreted as tissue induction. By inducing DFF45 protein, the DNase activity of DFF40 is blocked as described already in the introduction, thus allowing cancer cells to avoid the DNA-fragmentation machinery immediately before the final step of apoptosis. Taken together, these new features of "procancer" and cancer clones should favor an increase in the number of descendants to accept abundant nutrients, and have a higher chance to survive by escaping the apoptotic machinery. Consequently, multiple malignant clones with invasive capabilities are produced.

Another interesting phenomenon identified in the present study is the different responses of papillomatous lesions and invasive carcinoma lesions to cut wounding (Fig. 2c, d). The paracrine secretion of VEGF by "procancer" clones in late-stage hyperplastic epidermis was also noted in papillomatous and invasive carcinomatous lesions (Fig. 1g-i, Table I). In large papillomatous lesions, the neovascularization process and regeneration of vascular endothelial cells seem to have been exhausted, although it was still present in small papillomatous lesions. However, in invasive carcinoma lesions, cell regeneration in response to cut-wounding was absent in vascular endothelial cells, and cut-wounding induced collapse of blood vessels. The massive coagulative necrosis of cancer cells by cut-wounding could be due to the loss of functions of blood vessels.

\section{REFERENCES}

Arden K.C., Pathak S., Frankel L.S., and Zander A.: Ag-NOR staining in human chromosomes: differential staining in normal and leukemic bone marrow samples. Int. J. Cancer 36, 647-649, 1985

Ayres J.G., Crocker J., and Skilbeck N.Q.: Differentiation of malignant from normal and reactive mesothelial cells by the argyrophil technique for nucleolar organizer region associated proteins. Thorax 43, 366-370, 1988.
Azuchi M., Baba H., Imura S., Noriki S., Imamura Y., and Fukuda M.: Demonstration of biological aggressiveness of bone giant cell tumor by the comparative study of immunohistochemical detection of DNA-instability test and cortical bone destruction by CT. Acta Histochem. Cytochem. 31, 401-410, 1998.

Bartek J., Iggo R., Gannon J., and Lane D.B.: Genetic and immunohistochemical analysis of mutant p53 in human breast cancer cell lines. Oncogene 5, 893-899, 1990.

Bolontrade M.F., Stern M.C., Binder R.L., Zenklusen J.C., Gimenez-Conti I.B., and Conti C.J.: Angiogenesis is an early event in the development of chemically induced skin tumors. Carcinogenesis 19, 2107-2113, 1998.

Bowden G.T., and Krieg P.: Differential gene expression during multistage carcinogenesis. Environ. Health Perspect. 93 51-56, 1991.

Bravo R., and Frank R.: Cyclin/PCNA is the auxiliary protein of DNA polymerase delta. Nature 326, 515-520, 1987.

Brown K., Buchmann A., and Balmain A.: Carcinogeninduced mutations in the mouse c-Ha-ras gene provide evidence of multiple pathways for tumor progression. Proc. Natl. Acad. Sci. USA 87, 538-542, 1990.

Carbonelli D.L., Duran H.A., Schwint A., and Molinari de Rey B.: Nucleolar organizer regions as a marker of incipient transformation in a model of experimental carcinogenesis. Virchows Arch. 425, 165-170, 1994.

Carmen C.W.Y., Christopher D.M., Paul L.N., John R.G., Julia C.B., and David A.L.: A comparison of proliferating cell nucleolar antigen (PCNA) immunostaining, nucleolar organizer region (AgNOR) staining and histological grading in gastrointestinal stromal tumour. J. Pathol. 166, 147-152, 1992.

Caulin C., Bauluz C., Gandarillas A., Cano A., and Quintanilla M.: Changes in keratin expression during malignant progression of transformed mouse epidermal keratinocytes. Exp. Cell Res. 204, 11-21, 1993.

Coghlan L.G., Gimenez-Conti I., Kleiner H.E., Fischer S.M., Rundhaug J.E., Conti C.J., Slaga T.J., and DiGiovanni J.: Development and initial characterization of several new inbred strains of SENCAR mice for studies of multistage skin carcinogenesis. Carcinogenesis 21, 641-646, 2000.

Colapietro A.M., Goodell A.L., and Smart R.C.: Characterization of benzopyrene-initiated mouse skin papillomas for Ha-ras mutations and protein kinase $\mathrm{C}$ levels. Carcinogenesis 14, 2289-2295, 1993.

Crocker J., and Naro P.: Nucleolar organizer regions in lymphomas. J. Pathol. 151, 111-118, 1987.

Cui W., Kemp C.J., Duffie E., Balmain A., and Akhurst R.J. Lack of transforming growth factor-beta 1 expression in benign skin tumors of p53 null mice is prognostic for a high risk of malignant conversion. Cancer Res. 54, 5831-5836, 1994.

Dervan P.A., Gilmartin L.G., Loftus B.M., and Carney D.N.: Breast carcinoma kinetics. Argyrophilic nucleolar organizer regions counts correlate with Ki-67 scores. Am. J. Pathol. 92, 401-407, 1989. 
Enari M., Sakahira H., Yokoyama H., Okawa K., Iwamatsu A., and Nagata S.: A caspase-activated DNase that degrades DNA during apoptosis, and its inhibitor ICAD. Nature 391, 43-50, 1998.

Finch J.S., Albino H.E., and Bowden G.T.: Quantitation of early clonal expansion of two mutant 61st codon c-Ha-ras alleles in DMBA/TPA treated mouse skin by nested PCR/RFLP. Carcinogenesis 17, 2551-2557, 1996.

Finlay C.A., Hinds P.W., Tan T.H., Eliyahu D., Oren M., and Levine A.J.: Activating mutations for transformation by $\mathrm{p} 53$ produce a gene product that forms an hsc 70-p53 complex with an altered half-life. Mol. Cell. Biol. 8, 531-539, 1988.

Fukuda M., Okamura R., Rohrbach R., Bohm N., and Fujita S.: Changes in cell population kinetics during epidermal carcinogenesis. Cell Tissue Kinet. 11, 611-621, 1978.

Fukuda M., Miyoshi N., Hattori T., Sugihara H., Hosokawa Y., and Nakanishi K.: Different instability of nucleolar DNA at acid hydrolysis in cancerous and non cancerous cells as revealed by fluorescent staining with acridine orange. His tochem. $84,556-560,1986$.

Fukuda M., Noriki S., Imamura Y., Miyoshi N., Kimura S. Koizumi K., Suzuki K., Sakurai H., and Sakaguchi R.: Differential immunohistochemical staining of cancerous cells with anti-single-stranded DNA antiserum in ordinary pathologica paraffin section after DNA-denaturation by acid hydrolysis. Eur. J. Histochem. 37, 309-319, 1993.

Gimenez-Conti I., Aldaz C.M., Bianchi A.B., Roop D.R., Slaga T.J., and Conti C.J.: Early expression of type I K13 keratin in the progression of mouse skin papillomas. Carcinogenesis 11, 1995-1999, 1990.

Go C., Li P., and Wang X.J.: Blocking transforming growth factor $\beta$ signaling in transgenic epidermis accelerates chemical carcinogenesis: A mechanism associated with increased angiogenesis. Cancer res. 59, 2861-2868, 1999

Hollstein M., Sidransky D., Vogelstein B., and Haris C.C. p53 mutations in human cancers. Science 253, 49-53, 1991.

Huitfeldt H.S., Heyden A., Clausen O.P.F., Thrane E.V., Roop D., and Yuspa S.H.: Altered regulation of growth and expression of differentiation-associated keratins in benign mouse skin tumors. Carcinogenesis 12, 2063-2067, 1991.

Ishikawa T., Nakatsuru Y., Zarkovic M., and Shamsuddin A.M.: Inhibition of skin cancer by $\mathrm{IP}_{6}$ in vivo: initiation-promotion model. Anticancer Res. 19, 3749-3752, 1999.

Iversen O.H., and Eversen A.: Experimental skin carcinogenesis in mice. Acta Path. Microbiol. Scand. (Suppl) 156, 1962.

Iversen O.H., and Bjerkbes R.: Kinetics of epidermal reaction to carcinogenesis. Acta Path. Microbiol. Scand. (Suppl) 165, 1963

Iversen U., and Iversen O.H.: The sensitivity of the skin of hairless mice to chemical carcinogenesis. Cancer Res. 36, 12381241,1976

Iversen O.H., and Iversen U.M.: Must initiators come first? Tumorigenic and carcinogenic effects on skin of 3-methyl- cholanthrene and TPA in various sequences. Br. J. Cancer 45 , 912-920, 1982.

Jaskulski D., Deriel J.K., Mercer W.E., Calabretta B., and Baserga R.: Inhibition of cellular proliferation by antisense oligodeoxy nucleotides to PCNA cyclin. Science 240, 15441546,1988

Jordan E.G.: Nucleolar nomenclature. J. Cell. Sci. 67, 217220,1984

Kanitakis J., Hoyo E., Hermier C., Chouvet B., and Thivolet J.: Nucleolar organizer region enumeration in keratoacanthomas and squamous cell carcinomas of the skin. Cancer 69, 2937-2941, 1992.

Kemp C.J., Donehower L.A., Bradley A., and Balmain A.: Reduction of p53 gene dosage does not increase initiation or promotion but enhances malignant progression of chemically induced skin tumors. Cell 74, 813-822, 1993.

Kemp C.J., Burns P.A., Brown K., Nagase H., and Balmain A.: Transgenic approaches to the analysis of ras and p53 function in multistage carcinogenesis. Cold Spring Harbor Symp. Quant. Biol. 59, 427-434, 1994.

Khaled A., Imamura Y., Noriki S., and Fukuda M.: Early progression stage of malignancy of uterine cervical dysplasia as revealed by immunohistochemical demonstration of increased DNA-instability. Eur. J. Histochem. 44, 143-156, 2000.

Larcher F., Robles A.I., Duran H., Murillas R., Quintanilla M., Cano A., Conti C.J., and Jorcano J.L.: Up-regulation of vascular endothelial growth factor/vascular permeability factor in mouse skin carcinogenesis correlates with malignant progression state and activated H-ras expression levels. Cancer Res. 56, 5391-5396, 1996.

Leung D.W., Cachianes G., Kuang W.J., Goeddel D.V., and Ferrara N.: Vascular endothelial growth factor is a secreted angiogenic mitogen. Science 246, 1306-1309, 1989.

Liu X., Zou H., Slaughter C., and Wang X.: DFF, a heterodimeric protein that functions downstream of caspase-3 to trigger DNA fragmentation during apoptosis. Cell 89, 175-184, 1997.

Lu Y.P., Lou Y.R., Yen P., Newmark H.L., Mirochnitchenko O.I., Inouye M., and Huang MT.: Enhanced skin carcinogenesis in transgenic mice with high expression of glutathione peroxidase or both glutathione peroxidase and superoxide dismutase. Cancer Res. 57, 1468-1474, 1997

McGregor J.M., Yu C.C.W., Dublin E.A., Levison D.A., and MacDonald D.M.: Aberrant expression of p53 tumour-suppressor protein in non-melanoma skin cancer. Br. J. Dermatol 127, 463-469, 1992

Muscare M., Giuffre G., Tuccari G., and Barresi G.: Nucleolar organizer regions in dysplastic and neoplastic lesions of the large bowel. Eur. J. Histochem. 35, 401-408, 1991.

Nelson M.A., Futscher B.W., Kinsella T., Wymer J., and Bowden G.T.: Detection of mutant Ha-ras genes in chemically initiated mouse skin epidermis before the development of benign tumors. Proc. Natl. Acad. Sci. USA 89, 6398-6402, 1992. 
Nitta Y., Suzuki K., Kohli Y., Fujiki N., Imamura Y., Noriki S., and Fukuda M.: Early progression stage of malignancy of human colon border-line adenoma as revealed by immunohistochemical demonstration of increased DNA-instability. Eur. J. Histochem. 37, 207-218, 1993.

Otaki T., Kohli Y., Fujiki N., Imamura Y., and Fukuda M.: Early progression stage of malignancy as revealed by immunohistochemical demonstration of DNA instability; I, Human gastric adenomas. Eur. J. Histochem. 38, 281-290, 1994.

Owens D.M., Wei S.J.C., and Smart R.C.: A multihit, multistage model of chemical carcinogenesis. Carcinogenesis 20, 1837-1844, 1999.

Reddig P.J., Dreckschmidt N.E., Ahrens H., Simsiman R., Tseng C.P., Zou J., Oberley T.D., and Verma A.K.: Transgenic mice overexpressing protein kinase $\mathrm{Cd}$ in the epidermis are resistant to skin tumor promotion by 12 -o-tetradecanoylphorbol-13-acetate. Cancer Res. 59, 5710-5718, 1999.

Reeves B.R., Casey G., Honeycombe J.R., and Smith S.: Correlation of differentiation state and silver staining of nucleolar organizers in the promyelocytic leukemia cell line HL-60. Cancer Genet. Cytogenet. 13, 159-166, 1984.

Ren Z.P., Ponten F., Nister M., and Ponten J.: Two distinct p53 immunohistochemical patterns in human squamous-cell skin cancer, precursors and normal epidermis. Int. J. Cancer 69, 174-179, 1996

Ro Y.O., Cooper P.N., Lee J.A., Quinn A.G., Harrison D., Lane D., Horne C.H.W., Rees J.L., and Angus B.: p53 protein expression in benign and malignant skin tumors. Br. J. Dermatol. 128, 237-241, 1993.

Robles A.I., and Conti C.J.: Early overexpression of cyclin D1 protein in mouse skin carcinogenesis. Carcinogenesis 16, 781786, 1995.

Ruggeri B., Caamano J., Goodrow T., DiRado M., Bianchi A., Trono D., Conti C.J., and Klein-Szanto A.J.P.: Alterations of the p53 tumor suppressor gene during mouse skin tumor progression. Cancer Res. 51, 6615-6621, 1991.

Sabol S.L., Li R., Lee T.Y., and Abdul-Khalek R.: Inhibition of apoptosis-associated DNA fragmentation activity in nonapoptotic cells: the role of DNA fragmentation factor- 45 (DFF45/ICAD). Biochem. Biophys. Res. Commun. 253, 151$158,1998$.

Sakahira H., Enari M., and Nagata S.: Cleavage of CAD inhibitor in CAD activation and DNA degradation during apoptosis. Nature 391, 96-99, 1998.

Saran A., Pazzaglia S., Rebessi S., Bouthillier Y., Pioli C., Covelli V., Mouton D., Doria G., and Biozzi G.: Skin tumorigenesis by initiators and promoters of different chemical structures in lines of mice selectively bred for resistance (Carr) or susceptibility (Car-s) to two-stage skin carcinogenesis. Int. J. Cancer 83, 335-340, 1999.

Sasaki H., Suzuki T., Funaki N., Hoshi T., Iwabuchi M., Ohi R., and Sasano H.: Immunohistochemistry of DNA fragmentation factor in human stomach and colon: its correlation to apoptosis. Anticancer Res. 19, 5277-5282, 1999.
Soballe P.W., Montone K.T., Satyamoorthy K., Nesbit M., and Herlyn M.: Carcinogenesis in human skin grafted to SCID mice. Cancer Res. 56, 757-764, 1996.

Stenback F., Makinen M., and Jussila T.: p53 expression in skin carcinogenesis and its relationship to cell proliferation and tumour growth. Eur. J. Cancer 34, 1415-1424, 1998.

Stern M.C., Gimenez-Conti I.B., Budunova I., Coghlan L., Fischer S.M., DiGiovanni J., Slaga T.J., and Conti C.J.: Analysis of two inbred strains of mice derived from the SENCAR stock with different susceptibility to skin tumor progression. Carcinogenesis 19, 125-132, 1998.

Tober K.L., Cannon R.E., Spalding J.W., Oberyszyn T.M., Parrett M.L., Rackoff A.I., Oberyszyn A.S., Tennant R.W., and Robertson F.M.: Comparative expression of novel vascular endothelial growth factor/vascular permeability factor transcripts in skin, papillomas, and carcinomas of v-Ha-ras Tg.AC transgenic mice and FVB/N mice. Biochem. Biophys. Res. Commun. 247, 644-653, 1998

Trere D., Farabegoli F., Cancellieri A., Ceccarelli C., Eusebi V., and Derenzini M.: AgNOR area in interphase nuclei of human tumours correlates with the proliferative activity evaluated by bromodeoxyuridine labelling and Ki-67 immunostaining. J. Pathol. 165, 53-59, 1991.

Tsuji T.: Keratoacanthoma and squamous cell carcinoma: study of PCNA and LeY expression. J. Cutan. Pathol. 24, 409415, 1997.

Tsuzuki H., Saito H., Imamura Y., Noriki S., and Fukuda M.: Early progression stage of malignancy as revealed by immunohistochemical demonstration of DNA instability II, Otorhinolaryngeal border-line neoplastic lesions. Eur. J. Histochem. 38, 291-302, 1994.

Vassar R., Hutton M.E., and Fuchs E.: Transgenic overexpression of transforming growth factor alpha bypasses the need for c-Ha-ras mutations in mouse skin tumorigenesis. Mol. Cell. Biol. 12, 4643-4653, 1992.

Wei S.J.C., Chang R.L., Merkler K.A., Gwynne M., Cui X.X., Murthy B., Huang M.T., Xie J.G., Lu Y.P., Lou Y.R., Jerina D.M., and Conney A.H.: Dose-dependent mutation profile in the c-Ha-ras proto-oncogene of skin tumors in mice initiated with benzopyrene. Carcinogenesis 20, 1689-1696, 1999.

Wong R.L., Katz M.E., Ogata K., Tan E.M., and Cohen S.: Inhibition of nucleolar DNA synthesis by an autoantibody to proliferating cell nucleolar antigen/cyclin. Cell Immunol. 110, 443-448, 1987.

Yang L., Hashimura K., Qin C., Shrestha P., Sumitomo S., and Mori M.: Immunoreactivity of proliferating cell nucleolar antigen in salivary gland tumors: an assessment of growth potential. Virchows Arch. 422, 481-486, 1993.

Zhang B., Satoh M., Nishimura N., Suzuki J.S., Sone H., Aoki Y., and Tohyama C.: Metallothionein deficiency promotes mouse skin carcinogenesis induced by 7,12-dimethylbenzanthracene. Cancer Res. 58, 4044-4046, 1998. 